\title{
Listy Zygmunta Celichowskiego do Alfonsa Parczewskiego
}

Streszczenie: Artykuł przedstawia, zachowane w Litewskim Państwowym Archiwum Historycznym w Wilnie, listy Zygmunta Celichowskiego do Alfonsa Parczewskiego, związane z prowadzoną przez nich działalnością społeczną.

SŁowa KLuczowe: Zygmunt Celichowski, Alfons Parczewski, korespondencja.

Pośród obszernej korespondencji przechowywanej w spuściźnie po Alfonsie Parczewskim w Litewskim Państwowym Archiwum Historycznym w Wilnie (Lietuvos valstybes istorijos archyvas), w zespole Towarzystwo Przyjaciół Nauk w Wilnie (nr 1135 inwentarz 16 A. Parczewski), znalazło się pięć listów z lat 1884-1900, pisanych do Parczewskiego przez Zygmunta Celichowskiego, które - wydaje się - stanowią fragment korespondencji między obu panami. Wskazuje na to między innymi informacja o wysłanym przez Celichowskiego liście, który się nie zachował' ${ }^{1}$.

Autor listów, Zygmunt Celichowski², z Kórnikiem związany był od roku 1869; w tymże roku został sekretarzem Jana Kantego Działyńskiego. Od kwietnia 1870 roku kierował Biblioteką Kórnicka, której zbiory porządkował i stale powiększał - szczególnie zasób rękopisów, dawnych druków i grafiki - a także udostępniał. Kierował również pracami konserwatorskimi i introligatorskimi. Ponadto był pełnomocnikiem Działyńskiego (od $1876 \mathrm{roku}$ ), a później Władysława Zamoyskiego (od 1880 roku), do spraw administracyjnych i gospodarczych Kórnika. W 1871 roku uzyskał doktorat $\mathrm{z}$ historii.

\footnotetext{
${ }^{1}$ List Celichowskiego do Parczewskiego datowany: Kórnik, 10 kwietnia 1884.

${ }^{2}$ Informacje na temat Celichowskiego opracowane zostały na podstawie haseł zamieszczonych w Słowniku pracowników ksiażki polskiej, Warszawa-Łódź 1972, s. 105-106 oraz w Wielkopolskim słowniku biograficznym, Warszawa-Poznań 1983, s. 97.
} 
Celichowski popularyzował Bibliotekę Kórnicką ogłaszając artykuły i rozprawy o tematyce bibliograficznej i historycznej. Kórnickie zasoby były podstawą do przesyłania przez niego uzupełnień do Bibliografii polskiej Karola Estreichera. Rozwinął produkcję wydawniczą biblioteki: na podstawie zbiorów wydawał źródła historyczne i teksty staropolskie, a także kontynuował rozpoczęte przez Tytusa Działyńskiego wydawnictwo Acta Tomiciana.

Celichowski prowadził też szeroką działalność społeczną i oświatową. Pracował w Poznańskim Towarzystwie Przyjaciół Nauk, był członkiem bądź organizatorem stowarzyszeń społecznych, gospodarczych i oświatowych, m.in.: Polskiego Banku Handlowego, Towarzystwa Szerzenia Wstrzemięźliwości, Towarzystwa Czytelni Ludowych. Redagował i wydawał czasopisma „Kórniczanin” (1875) i „Pobudka do Szerzenia Wstrzemięźliwości" (1891-1896) oraz zapełniał je swoimi artykułami. W 1887 roku został właścicielem księgarni Jana Konstantego Żupańskiego w Poznaniu, którą prowadził do końca życia. W roku 1922 Uniwersytet Poznański nadał mu tytuł honorowego profesora historii.

Adresat listów, prawnik Alfons Parczewski, po studiach na Wydziale Prawa i Administracji oraz aplikacji sądowej w Warszawie, w 1872 roku, otrzymał mianowanie na pełniącego obowiązki adwokata w Trybunale Cywilnym w Kaliszu. Od połowy 1876 do sierpnia 1917 roku był adwokatem przysięgłym, choć w sierpniu 1914 roku wyjechał z Kalisza. Poza pracą zawodową i praktyką prywatną prowadził bardzo aktywną działalność społeczną; występował w licznych instytucjach i stowarzyszeniach, które często zakładane były z jego inicjatywy. Działał w Towarzystwie Muzycznym, Kaliskim Towarzystwie Wioślarskim, Towarzystwie Popierania Rosyjskiego Przemysłu i Handlu, Towarzystwie Wzajemnego Kredytu, Kaliskim Towarzystwie Dobroczynności, Towarzystwie Kredytowym Miasta Kalisza, Towarzystwie Pożyczkowo-Oszczędnościowym, kaliskiej Straży Ogniowej, Towarzystwie Prawniczym, Towarzystwie Oświatowym i w Towarzystwie Krajoznawczym³ ${ }^{3}$.

Interesowały go kwestie mniejszości narodowych, szczególnie Łużyczan. Przez kilka dziesięcioleci (1875-1906) odbywał podróże na Łużyce, na których rzecz podejmował wiele inicjatyw. Poza tym w kręgu jego zainteresowań pozostawały zagrożone germanizacją kresy polskie; odbył

${ }^{3}$ Na temat Parczewskiego zob. m.in.: K. Pol, Poczet prawników polskich, Warszawa 2000, s. 421-439; K. Walczak, Alfons Parczewski - historyk $i$ kaliszanin, „Rocznik Kaliski" 1990, t. 22, s. 21-31; E. Andrysiak, Książka i ludzie książki w życiu i pracy Alfonsa Parczewskiego, Kalisz 2005; eadem, Alfons Parczewski. Kaliszanin - rektor Wszechnicy Wileńskiej, Kalisz 2010. 
wędrówki po Śląsku Dolnym, Górnym i Cieszyńskim, po Kaszubach i Mazurach, interesował się Wileńszczyzną i Chełmszczyzną. Efektem podróży po Śląsku Średnim ${ }^{4}$ było wydawanie przez Parczewskiego w latach 1884-1891 we Wrocławiu pisma dla ewangelików zatytułowanego „Nowiny Śląskie".

Parczewski prowadził także działalność polityczną. W latach 1906-1914 był posłem do rosyjskiej Dumy Państwowej, w której reprezentował ziemię kaliską.

Po zniszczeniu Kalisza przez wojska niemieckie w sierpniu 1914 roku wyjechał do Warszawy; tam w 1915 roku organizował Wydział Prawa na reaktywowanym Uniwersytecie Warszawskim i został jego dziekanem. Kilka lat później (1919) przeniósł się do Wilna, gdzie zaproponowano mu pracę we wskrzeszonej Wszechnicy Wileńskiej. Zajął się tworzeniem Wydziału Prawa, ale dbał również o rozwój biblioteki uniwersyteckiej; wchodził w skład Komisji Bibliotecznej, był także inicjatorem założenia Towarzystwa Przyjaciół Biblioteki (1924). Sprawy biblioteki zawsze były dla niego ważne. W okresie gdy pełnił funkcję rektora Uniwersytetu Stefana Batorego (1922/1923, 1923/1924), czynił starania o sprowadzenie z Kórnika kolekcji Joachima Lelewela, przeznaczonej pierwotnie dla wileńskiej uczelni, którą opiekował się Zygmunt Celichowski. W czerwcu 1923 roku, kiedy Parczewski zwrócił się do Zarządu Biblioteki w Kórniku o zwrot tego księgozbioru, Celichowski już nie żył (zm. 26 stycznia 1923 roku); zbiory trafiły do Wilna na przełomie 1925 i 1926 roku. Na Uniwersytecie Stefana Batorego Parczewski wykładał jeszcze do 1930 roku, a rok wcześniej otrzymał doktorat honoris causa tegoż uniwersytetu.

Do dziś podziw budzą szerokie zainteresowania Parczewskiego, które znalazły odbicie także w zgromadzonym przez niego księgozbiorze.

Prezentowane poniżej listy pisane były w różnym czasie: po jednym w latach 1884, 1895, 1897, 1899 i 1900. Podejmowana w nich tematyka dotyczy głównie kwestii związanych z Towarzystwem Popierania Przemysłu Domowego, choć jest i akcent kaliski.

W roku 1884 Celichowski zwracał się do Parczewskiego z prośbą o pomocw sprawieodszukania w kaliskim archiwum potwierdzenia przywileju Augusta III dla Bractwa Strzeleckiego w Bninie. Sprawa - jak widać była dla kórnickiego bibliotekarza bardzo ważna, przypominał bowiem Parczewskiemu, że kilka tygodni wcześniej wysłał do niego list dotyczący tej kwestii. Nie wiadomo, czy Parczewskiemu udało się sprostać zadaniu i odnaleźć poszukiwany dokument.

\footnotetext{
${ }^{4}$ Śląsk Średni - terminem tym Parczewski określał tereny dzisiejszej Opolszczyzny.
} 
Trzy listy - z sierpnia 1895, maja 1897 i września 1899 roku - dotyczą spraw przemysłu domowego, a właściwie utworzonego w Poznaniu w 1897 roku Towarzystwa Popierania Przemysłu Domowego. Celichowski, opisując sytuację towarzystwa, zwracał uwagę na fakt, że zarząd postanowił rozwiązać je niezgodnie ze statutem i przekazać fundusze Związkowi Towarzystw Przemysłowych bądź Towarzystwu Pomocy Naukowej. Zagadnienia przemysłu domowego interesowały kaliskiego adwokata, który we wrześniu 1893 roku na III zjeździe prawników i ekonomistów polskich w Poznaniu wystąpił z referatem poświęconym właśnie przemysłowi domowemu (O przemyśle domowym ze szczególnym uwzględnieniem ekonomicznych potrzeb Wielkopolski) $)^{5}$. Celichowski, uważając zagadnienie przemysłu domowego za bardzo ważne, myślał, by i w Kórniku zająć się tą kwestią.

W 1900 roku Parczewski zorganizował w Kaliszu wystawę archeologiczną i zabytków sztuki i na jej otwarcie zapraszał Celichowskiego. Niestety kórnicki bibliotekarz do Kalisza nie mógł przyjechać - przeszkodził mu w tym stan zdrowia:

Zmuszony przeto jestem odmówić sobie przyjemności i zwiedzenia wystawy i powitania Pana Mecenasa - i poznania Kalisza, którego - ze wstydem to wyznaję - dotychczas nie znam 6 .

Otwarcie kaliskiej wystawy $\mathrm{w}$ salach reprezentacyjnych ratusza odbyło się 25 maja. Prezentowane były na niej także rękopisy, starodruki (w tym kaliskie), druki kaliskie, plany i mapy. Parczewski wystawiał między innymi rękopisy i druki ze swoich zbiorów - był także autorem wydanego z tej okazji katalogu.

Na podstawie kilku zaledwie listów z okresu 1884-1900 trudno wyrokować, czy Celichowski utrzymywał kontakty z Parczewskim po roku 1900. Kwestię tę mogłoby wyjaśnić opracowanie spuścizny po Celichowskim, w tym korespondencji przechowywanej w Bibliotece Kórnickiej oraz w Bibliotece Zakładu Narodowego im. Ossolińskich we Wrocławiu ${ }^{7}$.

${ }^{5}$ Wystąpienie ukazało się drukiem w następnym roku: Poznań 1894.

${ }^{6}$ Z listu Celichowskiego do Parczewskiego datowanego: Kórnik, 16 maja 1900.

7 Pragnę podziękować panu profesorowi Arturowi Kijasowi za wnikliwe przejrzenie tekstu artykułu i udzielone wskazówki. 


\section{Mórnit, 16 majà 1900 .}

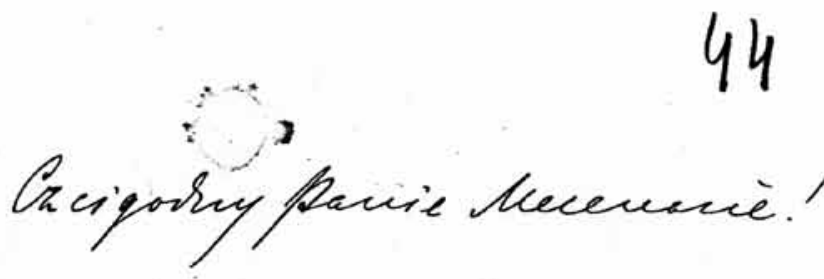

of nuits descis wielts pryjicuma jig lissgetarlen w incyen cracce 2 Taslawrgo pofuromecuà ua wystows Nelisks, Mhecuis etol.

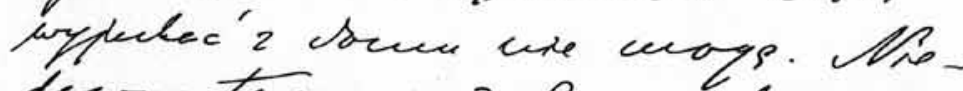

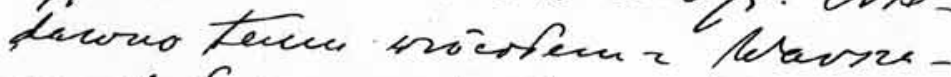

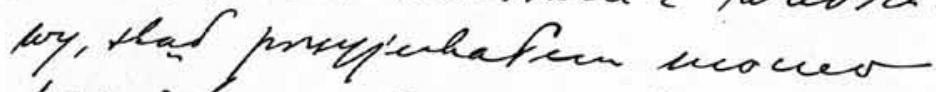
puerishracy it zerodeacer.

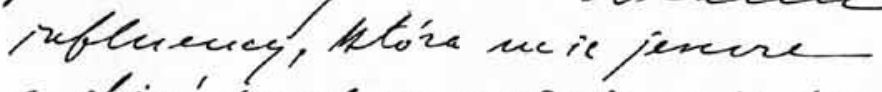
e objic' kydt weferuit wie ky-

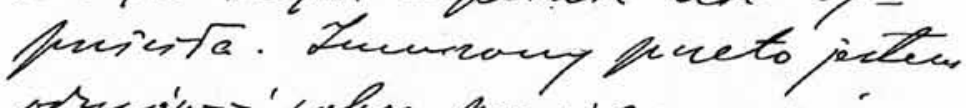

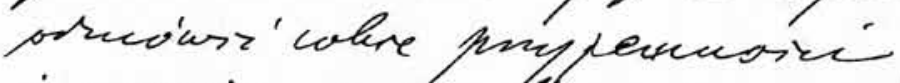

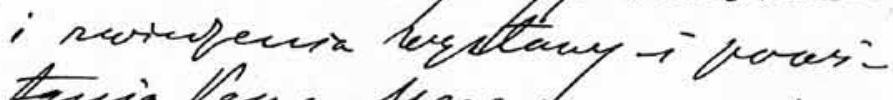
truia lawa Necectaca-; for-

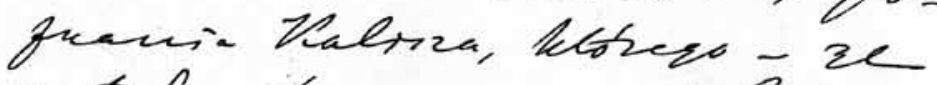

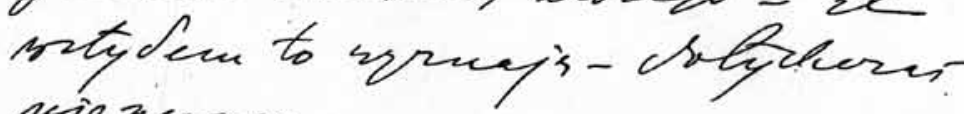
Niszeras.

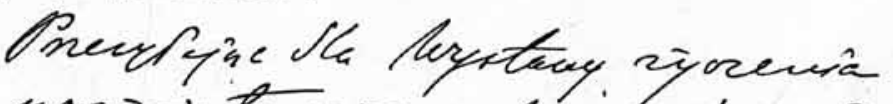

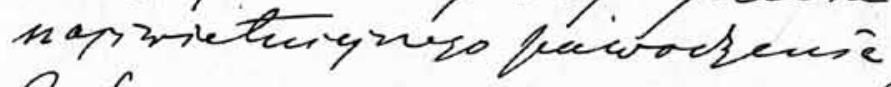

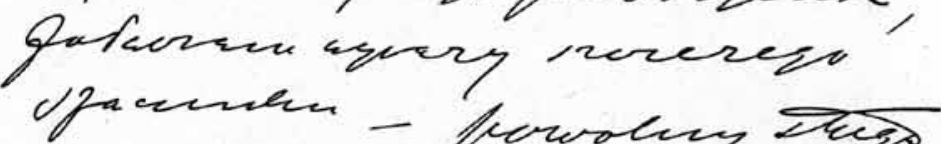

List Zygmunta Celichowskiego do Alfonsa Parczewskiego datowany: Kórnik, 16 maja 1900; odbitka ze zbiorów Litewskiego Państwowego Archiwum Historycznego w Wilnie 
Kórnik 10 kwietnia 1884.

\section{Łaskawy Panie}

Oddawca niniejszego listu p. Tulewicz ${ }^{8}$ jedzie do Kalisza w interesie handlowym, o którym Panu sam opowie. Ponieważ nie ma w Kaliszu żadnych znajomych, przeto śmiem prosić Pana, abyś Pan był łaskaw w razie potrzeby udzielić p. Tulewiczowi informacyi i wskazówek, któreby mu pomogły do zoryentowania się w handlowych i przemysłowych stosunkach Kalisza i okolicy.

Przy tej sposobności pozwolę sobie przypomnieć prośbę, którą wysłałem do Pana przed kilku tygodniami w sprawie poszukiwań w Archiwum Kaliskiem ${ }^{9}$ aprobacyi przywileju Augusta III $^{10}$ danego bractwu Strzeleckiemu w Bninie ${ }^{11}$. Racz mię przez p. Tulewicza słówkiem objaśnić, czy nie masz widoków odszukania tej aprobacyi w archiwum?

Przepraszając za narzucanie się Panu z memi petycyami, łączę zapewnienie wzajemnej gotowości do usług wraz z wyrazami szczerego szacunku.

powolny sługa

Dr. Celichowski

${ }^{8}$ L. Tulewicz - jego nazwisko pojawiło się w ogłoszeniu zamieszczonym w „,Kórniczaninie” (1875, nr 19), redagowanym przez Celichowskiego („„«Pług» Spółka akcyjna w Kórniku poszukuje ucznia do swego handlu żelaza. Zgłoszenia się przyjmuje L. Tulewicz w Kórniku").

${ }^{9}$ Archiwum w Kaliszu - pierwsze, pod nazwą Archiwum Akt Dawnych, powstało na mocy decyzji namiestnika Królestwa Polskiego z 16 marca 1825 roku; przechowywało głównie akta sądowe dawnych sądów grodzkich i ziemskich oraz akta miast z okresu staropolskiego. W 1888 roku zostało zlikwidowane przez władze carskie, a jego zasób przeniesiono do Archiwum Głównego Królestwa Polskiego w Warszawie. Zorganizowane ponownie w 1920 roku, działało do roku 1926 (likwidacja na skutek sejmowej uchwały oszczędnościowej). Placówkę archiwalną przywrócono Kaliszowi w roku 1950 (Powiatowe Archiwum Państwowe, Oddział Terenowy Archiwum Miasta Poznania i Województwa Poznańskiego, obecnie Archiwum Państwowe w Kaliszu).

${ }^{10}$ August III (Sas) (1696-1763) z dynastii Wettynów, w latach 1733-1763 król Polski i wielki książę litewski, a także dziedziczny książę saski i książę elektor.

${ }^{11}$ Bractwo Strzeleckie w Bninie - powołane do życia, równocześnie z bractwem w Kórniku, na prośbę starościny łęczyckiej Teofilii z Działyńskich Szołdrskiej-Potulickiej, ukazem królewskim Augusta III z dnia 9 stycznia 1745 roku. Na terenie zaboru pruskiego bractwa mogły kontynuować działalność, spotykały się jednak z naciskami germanizacyjnymi. W drugiej połowie XIX wieku organizacje strzeleckie zaczęły się odradzać, prawdziwy renesans przeżywały bractwa wielkopolskie. Dzisiaj bractwo to funkcjonuje pod nazwą Kórnicko-Bnińskie Bractwo Kurkowe. 
Kórnik 24.8.1895.

\section{Łaskawy Panie Mecenasie!}

Pozwalam sobie powtórnie odezwać się w sprawie proponowanej narady, o to, aby się zapytać, czy zgoda na to, abym na ową naradę zaprosił także p. dra. Drobnika $^{12} \mathrm{z}$ Poznania, członka Wydziału Towarzystw Przemysłowych ${ }^{13}$, który się także wiadomą sprawą interesuje a z którym o niej już mówiłem. Racz mi Pan donieść, czy nie masz jakiej przeszkody w zaproszeniu p. dra. Drobnika na ową naradę tyczącą się przemysłu domowego.

Z prawdziwym szacunkiem

powolny sługa

Dr. Celichowski

Kórnik, 21 maja 1897.

\section{Łaskawy Panie Mecenasie!}

Przy samem zawiązywaniu Towarzystwa popierania przemysłu domowego ${ }^{14}$ nie miałem wiary, że sprawa pójdzie raźno. Dlatego też nie przyjąłem wyboru do

12 Tomasz Drobnik (1858-1901), lekarz chirurg, działacz społeczny. W 1885 roku uzyskał stopień doktora medycyny. Osiadł w Poznaniu w 1890 roku, a w następnym roku został kierownikiem oddziału chirurgicznego w Szpitalu Dziecięcym św. Józefa, zaś w roku 1899 naczelnym chirurgiem w Szpitalu Miejskim. Działał w Wydziale Lekarskim Poznańskiego Towarzystwa Przyjaciół Nauk (PTPN), w Towarzystwie Kolonii Wakacyjnych dla Dzieci „Stella” oraz w Towarzystwie Młodych Przemysłowców w Poznaniu (prezes). Należał do założycieli polskiej Lecznicy Poznańskiej i był współzałożycielem Towarzystwa Gimnastycznego „Sokół” w Wielkopolsce.

${ }^{13}$ Wydział Towarzystw Przemysłowych w Poznaniu - chodzi prawdopodobnie nie o wydział, lecz o Dyrekcję Towarzystw Przemysłowych; wydziału nie wymienia żaden z historyków zajmujących się dziejami Poznania. Towarzystwo Przemysłowe w Poznaniu utworzono w maju 1848 roku. Do jego założycieli należeli m.in.: Karol Libelt, Jędrzej Moraczewski, Hipolit Cegielski i Tytus Działyński. Towarzystwo było organizatorem wystawy przemysłowej w Poznaniu (1850), założycielem pierwszej polskiej szkoły zawodowej, dzięki jego staraniom powstała Spółka Pożyczkowa, przekształcona później w Bank Przemysłowców. W 1889 roku towarzystwo założyło „Dom Przemysłowy”.

14 Towarzystwo Popierania Przemysłu Domowego - towarzystwo miało na celu aktywizację drobnych wytwórców zarówno na wsi, jak i w mieście. Zgodnie z intencją projektodawców powinno ono przeciwdziałać utracie przez nich w następstwie konkurencji - warsztatów i punktów usługowych. Nie wyszło jednak poza ramy projektu. Rzeczywistość i polityka zaborcy stanowiły przeszkodę $\mathrm{w}$ jego urzeczywistnieniu. 
zarządu. Przypuszczenie moje nie omyliło mię, - towarzystwo można uważać za pogrzebane - a przynajmniej popadłe w ciężki letarg, z którego budzić je nie czuję ani sił ani chęci. Nie wchodzę w rozbiór przyczyn, dla których towarzystwo kulało i kuleje - a pewnie i nadal kuleć będzie. Byłoby dowodem zarozumiałości, gdybym miał brać ster tej sprawy w moje ręce, skoro go dotychczas trzyma p. dr. Łebiński ${ }^{15}$, pomijam już to, że $\mathrm{z}$ formalnych przyczyn byłoby to rzeczą niemożliwą. W pierwszej linji powinien się tą sprawą zająć dotychczasowy zarząd a zatem pp. Łebiński, M. Jackowski ${ }^{16}$, Wł. Jerzykiewicz ${ }^{17}$, Wojciech Łubieński ${ }^{18}$, Wł. Chosłowski ${ }^{19}$, W. Bryliński ${ }^{20}$ (jeden z członków zarządu - B. Leitgeber ${ }^{21}$ umarł).

${ }^{15}$ Władysław Łebiński (1840-1907), publicysta i działacz wielkopolski. Studiował filologię i historię na Uniwersytecie Wrocławskim (1858-1862), w 1863 roku uzyskał doktorat z historii Polski, brał udział w powstaniu styczniowym. W 1870 roku osiadł w Poznaniu i rozpoczął działalność w Towarzystwie Przemysłowym. Należał do założycieli Towarzystwa Czytelni Ludowych (1880) i Banku Ziemskiego (1886), działał też w Towarzystwie Ubezpieczeń „Westa” i w PTPN. Zakupił drukarnię założoną przez Józefa Ignacego Kraszewskiego w Dreźnie, którą przewiózł do Poznania i rozwinął. Był redaktorem „Roczników Poznańskiego Towarzystwa Przyjaciół Nauk” (1882-1889) i „Dziennika Poznańskiego” (listopad 1896-1907).

${ }^{16}$ Maksymilian Jackowski (1815-1905), od 1842 roku był zarządcą dóbr na Podolu, a w latach 1850-1885 mieszkał w Pomarzanowicach. Za udział w powstaniu styczniowym był więziony w Berlinie. Zasłużył się jako działacz społeczny i gospodarczy, wspierał szczególnie zakładanie i działalność kółek rolniczych: w latach 1873-1900 był ich patronem w Wielkim Księstwie Poznańskim. Parał się także publicystyką.

17 Władysław Jerzykiewicz (1837-1920), działacz gospodarczy, społeczny i polityczny. W 1860 roku otworzył w Poznaniu sklep bławatny. Po roku 1870 prowadził tylko działalność społeczną i gospodarczą. Należał do założycieli Spółki Akcyjnej „Teatr Polski w Ogrodzie Potockiego", założył Spółkę Budowlaną „Pomoc”, był współinicjatorem utworzenia Banku Włościańskiego (1872). Brał też udział w zakładaniu Banku Ziemiańskiego (1886) i działał w towarzystwie akcyjnym „Dziennik Poznański”. Współdziałał z organizacjami oświatowymi i naukowymi. Był członkiem PTPN i Towarzystwa Pomocy Naukowej im. K. Marcinkowskiego (później prezes). Był posłem polskim do sejmu pruskiego (1899-1908).

${ }^{18}$ Wojciech Łubieński (1856-1903), ziemianin, poseł na sejm pruski, współpracownik „Wielkopolanina”.

${ }^{19}$ Władysław Chosłowski (1845-1901), ziemianin z Głuchowa w powiecie krotoszyńskim, wielkopolski działacz gospodarczy, w latach 1876-1877 członek zwyczajny PTPN.

${ }^{20}$ Wincenty Bryliński (1846-1917), ekonomista, dyrektor Banku Przemysłowego w Poznaniu, w latach 1908-1917 członek zwyczajny PTPN.

${ }^{21}$ Bolesław Teodor Leitgeber (1835-1896), kupiec i ziemianin, właściciel firmy handlującej artykułami kolonialnymi w Poznaniu, prezes Zarządu Korporacji Kupców Chrześcijańskich w Poznaniu. Od 1874 roku dyrektor Towarzystwa Pożyczkowego, przekształconego w 1891 roku w Bank Przemysłowców, długoletni członek Zarządu Głównego Towarzystwa Czytelni Ludowych w Poznaniu. 
Ci panowie powinni się choćby raz jeden zebrać - i uchwalić co dalej zrobić: czy rozwiązać towarzystwo i przekazać pieniądze na pokrewny cel, - czy wybrać inny zarząd, - czy wreszcie - nie zmieniając niczego, zabrać się energicznie do pracy. Dzisiaj nie mogę nawet skarżyć się lub zwalać winy na obojętność ogółu - bo ten ogół nie wie nawet, że istnieje jakieś towarzystwo „ku popieraniu zarobkowości domowej i przemysłu domowego".

W obecnych stosunkach i w okolicznościach, w jakich się dzisiaj Towarzystwo znajduje, nie widzę dla siebie możności wzięcia w jego pracach czynnego udziału. A że sprawę przemysłu domowego uważam za bardzo ważna, dlatego przemyśliwam nad tem, żeby w Kórniku zrobić coś na własną rękę.

Szkoda, że P. Mecenas tak krótko zabawi w Poznaniu, bo byłaby to dobra sposobność zebrania zarządu na posiedzenie z okazyi bytności Pana Mecenasa i może by wreszcie Zarząd powziął jakąś decyzyę i popchnął sprawę trochę naprzód.

Załączam szczere pozdrowienia

powolny sługa

Dr. Celichowski

Kórnik, 4 września 1899.

Łaskawy Panie Mecenasie

Jak Panu wiadomo, zawiązało się w Poznaniu przed 3 laty Towarzystwo popierania przemysłu domowego, wybrało zarząd tymczasowy, wydrukowało Ustawy i zaczęło przyjmować składki, których przeważną część stanowiła suma, która wpłynęła z poza granic WKs. Poznańskiego ${ }^{22}$. Główna - a raczej cała akcya złożona była w ręce p. dra Łebińskiego. Od czasu wybrania Zarządu i wydrukowania Ustaw, Towarzystwo nie dało znaku życia.

W Ustawach jest przepis, że walne zebrania winny być zwoływane co rok. Od czasu założenia jednak walnego zebrania nie było. O ile zarząd sam był czynny, nie wiem, bo do zarządu nie należę.

${ }^{22}$ Wielkie Księstwo Poznańskie (1815-1848) - powstało na mocy decyzji kongresu wiedeńskiego, utworzone z części Księstwa Warszawskiego. W roku 1831, po powstaniu listopadowym w Królestwie Polskim, popartym przez społeczeństwo Wielkopolski, autonomia księstwa została ograniczona, a po powstaniach wielkopolskich $(1846,1848)$ - całkowicie zniesiona. Administracja pruska zmieniła nazwę Wielkiego Księstwa Poznańskiego na Prowincja Poznańska; w użyciu społecznym jednak nadal funkcjonowała dawna nazwa. 
Obecnie odbieram od p. dra. Łebińskiego doniesienie, że postanowiono Towarzystwo zwinąć po cichu - bez zwoływania walnego zebrania. P. dr Łebiński komunikuje się tylko z tymi, co złożyli większe składki i dlatego i mnie się zapytuje - z powodu składki złożonej przeze mnie w imieniu p. Wł. Zamoyskiego ${ }^{23}$. Ustawy jednakże przewidują że o rozwiązaniu Towarzystwa decyduje walne zebranie. Proponuje dalej p. dr Ł., aby fundusze Towarzystwa oddać Związkowi Towarzystw Przemysłowych ${ }^{24}$, pod warunkiem, że Związek pieniędzy tych użyje jako funduszu na te same cele. I to znów sprzeciwia się Ustawom, które opiewają że w razie rozwiązania Towarzystwa fundusze jego przechodzą na rzecz Towarz. Pomocy Naukowej ${ }^{25}$. - Odpisałem p. dr. Łebińskiemu, że mojem zdaniem należałoby się bądź co bądź stosować do Ustaw - semel iustus, semper [słowo nieczytelne], - a wiec należałoby zwołać walne zebranie.

Czy Związek użyłby tych funduszów na te same cele, nie śmiem przesądzać. Proponowałem, aby raczej Towarzystwo popierania przemysłu domowego przystąpiło do Związku - albo żeby w Związku utworzył się poprzednio osobny wydział dla przemysłu domowego.

Być może, że tak samo, jak dotychczasowy Zarząd, tak i Związek nie potrafi ożywić tej sprawy, - ale zdaje mi się, że nie należy od razu zwątpić, że się nic nie da zrobić, skoro dotychczasowy Zarząd nic nie zrobił. P. dr. Łebiński niezawodnie i do Pana Mecenasa udał się w tej sprawie. Mimo tego piszę osobno, choćby z tego tytułu, że przy pierwszem poruszeniu tej myśli miałem trochę udziału i że przez to i odrobina odpowiedzialności i na mnie ciąży. Wobec tego pragnąłbym, aby się wszystko przynajmniej po formie załatwiło.

Załączam wyrazy szczerego szacunku

powolny sługa

Dr Celichowski

${ }^{23}$ Władysław Zamoyski (1853-1924), w 1881 roku jako spadkobierca Jana Kantego Działyńskiego objął dobra kórnickie wraz z biblioteką i zbiorami muzealnymi. W 1885 roku opuścił Wielkopolskę i osiadł na Podhalu, a do Kórnika powrócił w 1920 roku. Cały majątek wraz z biblioteką przekazał w 1924 roku narodowi, tworząc fundację Zakłady Kórnickie.

${ }^{24}$ Związek Towarzystw Przemysłowych - założony w 1895 roku na zjeździe towarzystw przemysłowych, zrzeszał towarzystwa z Wielkiego Księstwa Poznańskiego, Górnego Śląska, a także działające poza obszarami polskimi.

${ }^{25}$ Poznańskie Towarzystwo Pomocy Naukowej - jego założycielem w 1841 roku był lekarz i społecznik Karol Marcinkowski, który stanął na czele zarządu. Zadaniem towarzystwa były pogłębianie polskiego dorobku naukowego i pomoc w edukacji ubogiej młodzieży, w myśl słów Marcinkowskiego: „Wychowanie nasze jest to dług zaciągniony u ogółu, z czego się w swym czasie wypłacać winniśmy". 
Kórnik, 16 maja 1900.

\title{
Czcigodny Panie Mecenasie!
}

Z miłą chęcią a wielką przyjemnością korzystałbym w innym czasie z łaskawego zaproszenia na wystawę kaliską. Obecnie atoli wyjechać z domu nie mogę. Niedawno temu wróciłem z Warszawy, skąd przyjechałem mocno przeziębiony i z zarodkami influency, która mnie jeszcze z objęć swych zupełnie nie wypuściła. Zmuszony przeto jestem odmówić sobie przyjemności i zwiedzenia wystawy i powitania Pana Mecenasa - i poznania Kalisza, którego - ze wstydem to wyznaję - dotychczas nie znam.

Przesyłając dla Wystawy życzenia najświetniejszego powodzenia, załączam wyrazy szczerego szacunku - powolny sługa

Dr. Celichowski

\section{EWA ANDRYSIAK}

\section{Letter exchange between Zygmunt Celichowski and Alfons Parczewski}

\begin{abstract}
Aвstract. This article discusses letters written by Zygmunt Celichowski to Alfons Parczewski. The letters are currently held in the Lithuanian Archives of Old Records in Vilnius. The letters concern the social activity performed by both the author and the recipient.
\end{abstract}

Key words: Zygmunt Celichowski, Alfons Parczewski, epistolography. 
